\title{
Analisa Sistem Antrian Loket pada PT. Tiki Jalan Teuku Umar Pekanbaru dengan Menggunakan Software Arena
}

\author{
Muhammad Nur ${ }^{1}$, Faulin Feratesia Qitri ${ }^{2}$ \\ ${ }^{1,2}$ Jurusan Teknik Industri, Fakultas Sains dan Teknologi, UIN Sultan Syarif Kasim Riau \\ JL. HR.Soebrantas No. 155 Simpang Baru, Panam, Pekanbaru, 28293 \\ Email:faulinqitri@gmail.com
}

\begin{abstract}
Abstrak
PT Citra Van Titipan Kilat (TIKI) adalah sebuah perusahaan yang bergerak di bidang jasa pengiriman barang (kurir), sudah memiliki pengalaman dalam melayani jasa pengiriman barang ke berbagai daerah di seluruh Indonesia, Sehingga menjadi suatu masalah bagi perusahaan ini mengenai sistem antriannya, terlihat bahwa rata-rata proses pelayanan sebesar 12,95 menit sedangkan rata-rata waktu kedatangan sebesar 2,5 menit. Maka terjadi antrian panjang karena adanya pelayanan yang membutuhkan waktu yang lama untuk bertransaksi dengan jumlah waktu yang terlalu besar, mengatasi masalah yang kaitan dengan antrian salah satunya adalah melakukan analisis pada sistem pelayanan dengan menggunakan teori antrian yang disimulasikan kedalam software ARENA 14.0. Dibandingkan skenario awal yang rata-rata waiting time sebesar 0,6 dan utilitas 0,8625 dengan skenario terpilih yaitu skenario 3 yang rata-rata waiting time didapatkan sebesar 0,119 dan utilitas sebesar 0,5686 , karena pelanggan yang datang dengan pelanggan yang keluar hampir sama, tidak banyak pelanggan yang tertinggal didalam, sehingga semua pelanggan dapat terlayani. Dapat dikatakan pada skenario 3 loket tidak sibuk dan waktu tunggu pada skenario 3 dapat terasi baik dengan penambahan 3 loket lagi. Penerapan pada perusahaan akan mengalami keuntungan besar karena pelanggan merasa puas dengan pelayanan yang cepat dan baik.
\end{abstract}

Kata kunci: Antrian, software ARENA, Utilitas, Skenario, Waiting Time

\section{Pendahuluan}

Antrian merupakan bagian permasalahan yang ada dalam kehidupan nyata yang sering kita hadapi setiap hari. Antrian tersebut terjadi karena kebutuhan pelayanan yang melebihi kapasitas pelayanan. Antrian adalah keseluruhan proses para pelanggan atau barang yang berdatangan dan memasuki barisan antrian yang memerlukan pelayanan. Untuk mempertahankan pelanggan, sebuah sistem selalu berusaha untuk memberikan pelayanan yang terbaik. Pelayanan yang terbaik tersebut diantaranya adalah memberikan pelayanan yang cepat sehingga pelanggan tidak dibiarkan menunggu terlalu lama (Arafat, 2013)

Begitu pentingnya sistem bagi suatu perusahaan maupun instansi hal ini karena sistem yang digunakan dapat memberikan keuntungan yang besar bagi suatu perusahaan. Begitupun dengan salah satu perusahaan yang bergerak dibidang jasa yaitu PT.TIKI Pekanbaru yang terletak di Jalan Teuku Umar. Perusahaan yang telah lama berdiri di Pekanbaru ini sudah memiliki pengalaman dalam melayani jasa pengiriman barang ke berbagai daerah di seluruh Indonesia, tentulah dengan dilihat dari besarnya perusahaan tersebut dibutuhkan sistem yang baik dalam menjalankan perusahaannya.

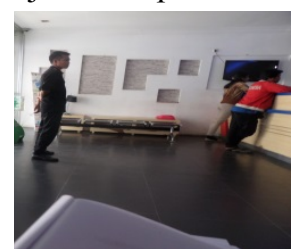

(a)

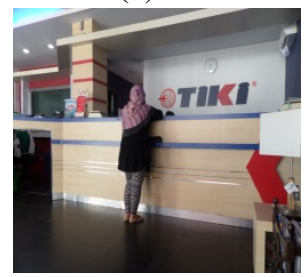

(c)

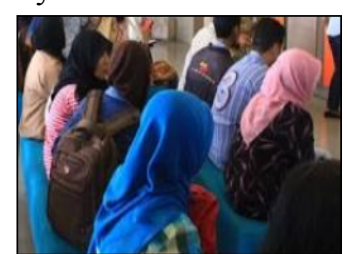

(b)

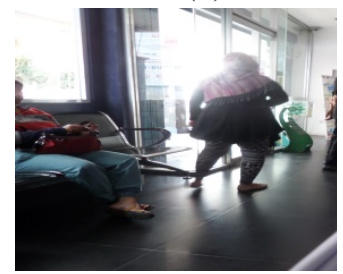

(d) 
Gambar 1.1 Pelanggan yang Mengantri pada PT. TIKI

Tabel 1.2 Rekapitulasi Tingkat Kepuasan Pelanggan

\begin{tabular}{|c|c|c|}
\hline No & $\begin{array}{c}\text { Nama } \\
\text { Pelanggan }\end{array}$ & $\begin{array}{c}\text { Tingkat Kepuasan } \\
(0-4)=\text { rendah, }(5- \\
\text { 8)=sedang, }(9-10)= \\
\text { tinggi }\end{array}$ \\
\hline 1 & Romi & 8 \\
\hline 2 & Susi & 5 \\
\hline 3 & Anggraini & 6 \\
\hline 4 & Sukarni & 5 \\
\hline 5 & Tina & 4 \\
\hline 6 & Karni & 5 \\
\hline 7 & Totok & 5 \\
\hline 8 & Lia & 6 \\
\hline 9 & Numah & 7 \\
\hline 10 & Laili & 7 \\
\hline 11 & Rian & 8 \\
\hline 12 & Jingga & 8 \\
\hline 13 & Orin & 9 \\
\hline 14 & Jihan & 5 \\
\hline 15 & Rafli & 6 \\
\hline 16 & Nando & 4 \\
\hline 17 & Winny & 5 \\
\hline 18 & Lufti & 4 \\
\hline 19 & Wijaya & 6 \\
\hline 20 & Vaniola & 8 \\
\hline \multicolumn{2}{|c|}{ TOTAL } & 121 \\
\hline \multicolumn{2}{|c|}{ RATA-RATA } & 6,05 \\
\hline
\end{tabular}

Sumber: Pengumpulan Data PT. TIKI (2016)

Berdasarkan Tabel 1.2 maka dapat dikatakan bahwa tingkat kepuasan pelanggan berada pada tingkat sedang, karena ada pelanggan yang terlalu lama menunggu, dan ada yang hanya sebentar. Mengenai sistem antrian ini ada berbagai hal yang dapat terjadi mungkin karena dari segi pelayanan dari operator yang bekerja atau faktor lain yang diluar dari kendali perusahaan tersebut, seperti memberikan kejenuhan bagi pelanggan yang menunggu lama. Oleh karena itu merasa tertarik untuk melakukan perbaikan permasalahan antrian tersebut.

\section{Kajian Pustaka}

\section{A. TIKI (Titipan Kilat)}

PT Citra Van Titipan Kilat (TIKI) adalah sebuah perusahaan yang bergerak di bidang jasa pengiriman barang (kurir) dan merupakan salah satu yang terbesar di Indonesia. PT. TIKI telah berdiri sejak tahun 1970.Melalui Bapak Soeprapto dan Nyonya Nuraini Soeprapto sebagai perintis usaha dan pemegang saham, jasa pengiriman barang TIKI mulai menapak dengan kokoh ditengah persaingan bisnis jasa pengiriman barang yang terus menggeliat seiring perkembangan teknologi yang modern dan kebutuhan masyarakat diseluruh dunia, khususnya masyarakat Indonesia .

\section{B. Definisi Standard Operational Procedure (SOP)}

Standard Operating Procedure (SOP) merupakan suatu rangkaian instruksi tertulis yang mendokumentasikan kegiatan atau proses rutin yang terdapat pada suatu perusahaan. Pengembangan dan penerapan dari Standard Operating Procedure (SOP) merupakan bagian penting dari keberhasilan sistem kualitas dimana Standard Operating Procedure (SOP) menyediakan informasi untuk setiap individu dalam perusahaan untuk menjalankan suatu pekerjaan, dan memberikan konsistensi pada kualitas dan integritas dari suatu produk atau hasil akhir (Handoko, 2013).

\section{Teori Antrian}

Antrian dalam bahasa inggris disebut queuing atau waiting line. Teori antrian berkenan dengan sejumlah aspek dari situasi dimana pelanggan harus antri untuk mendapatkan suatu layanan. Antrian digunakan untuk memecahkan masalah dibank, antrian pasien di ruang tunggu dokter, pembayaran belanja dikasir supermarket, pengisian bahan bakar, antrian servis di bengkel mobil,dan sebagainya. Karena menunggu memakan waktu, sementara waktu merupakan sumber daya yang berharga, maka pengurangan waktu menunggu merupakan tema menarik untuk dianalisis tetapi tidak berarti analisis antrian hanya membahas waktu menunggu (Wahyuningsih, 2013).

Teori antrian (Queuering Theory) merupakan studi matematika dari antrian atau kejadian garis tunggu (Waiting lines), yakni satu garis tunggu dari pelanggan yang memerlukan layanan dari sistem yang ada. Untuk mempertahankan pelanggan, sebuah organisasi selalu berusaha untuk memberikan pelayanan terbaik. Pelayanan yang terbaik tersebut diantaranya adalah memberikan pelayanan yang cepat sehingga pelanggan tidak dibiarkan 
menunggu (mengantri) terlalu lama. Namun demikian, dampak pemberi layanan yang cepat ini akan menimbulkan biaya bagi organisasi, karena harus menambah fasilitas layanan. Oleh karena itu, layanan yang cepat sangat membantu untuk mempertahankan pelanggan, yang dalam jangka panjang tentu saja akan meningkatkan keuntungan perusahaan (Wahyuningsih, 2013).

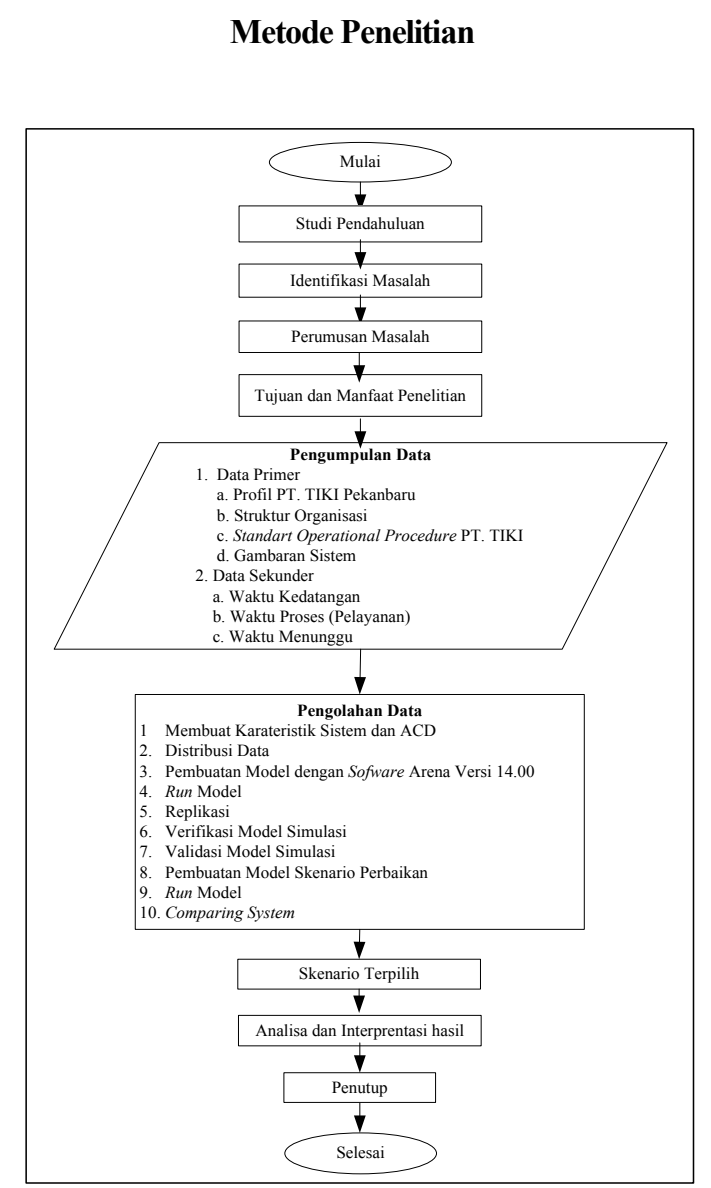

\section{Hasil Analisis dan Pembahasan}

\section{Verifikasi dan Validasi}

Dalam comparing system atau yang dikenal juga dengan uji perbandingan terdapat dua tahapan simulasi yaitu verifikasi dan validasi.

\section{Verifikasi Arena}

Verifikasi merupakan proses perbandingan antara model konseptual dengan model simulasi. Sehingga tujuan dilakukannya verifikasi adalah untuk mengecek apakah model simulasi yang telah dibuat sama dan sesuai dengan model konseptualnya.
Comparing system tanpa uji statistik dilakukan dalam verifikasi, yaitu dengan melakukan pengecekan ada tidaknya error dalam model Arena. Pada modul arena yang telah kelompok kami buat, berikut ini hasil yang kami dapatkan:

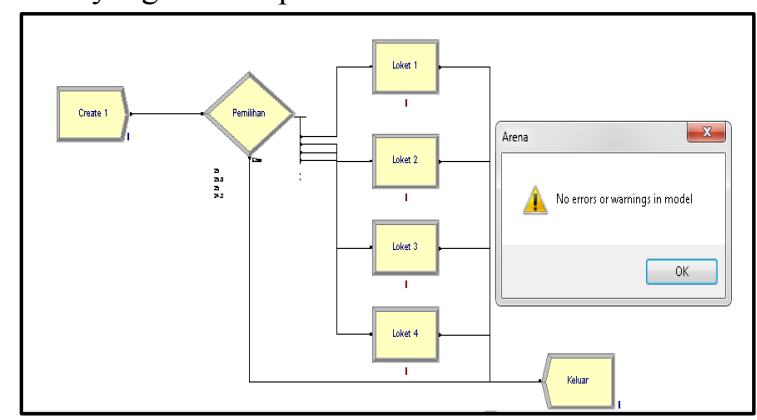

Gambar 4.19 Model ARENA

Arena mengeluarkan kotak dialog yang berarti simulasi yang dimodelkan tidak errors, sehingga dapat digunakan.

a. Jumlah Replikasi

Dalam simulasi dibutuhkan adanya replikasi Simulasi berdasarkan dari pembangkitan bilangan random. Jika bilangan random yang dibangkitkan baik, maka hasil simulasinya akan baik, sebaliknya jika bilangan random yang dibangkitkan buruk maka hasil simulasinya akan buruk pula. Untuk mengantisipasi terjadinya kesalahan pengambilan kesimpulan karena kondisi tersebut maka dibutuhkan adanya replikasi. Berikut adalah replikasi yang kelompok kami dapatkan.

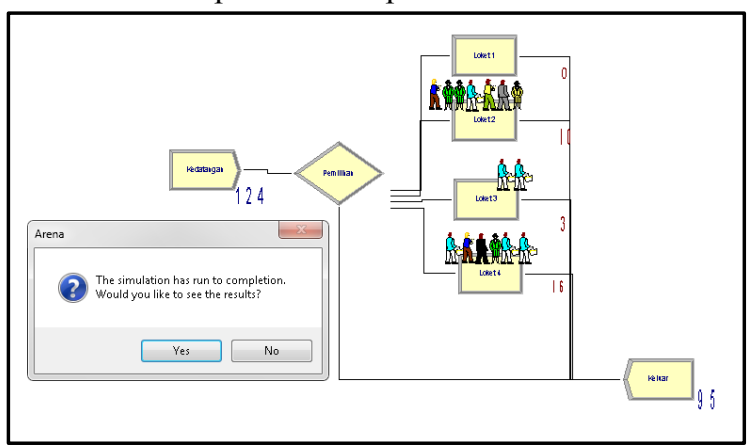

Gambar 4.20 Verifikasi Model Eksisting

Dari gambar diatas, dapat diketahui bahwa sudah tidak ada lagi error model simulasi yang telah kami buat atau dengan kata lain proses verifikasi model tersebut berhasil. 
Vol. 2, No. 2, 2016

Jurnal Hasil Penelitian dan Karya Ilmiah dalam Bidang Teknik Industri

\begin{tabular}{|c|c|c|}
\hline 4:45:33PM & Category Overview & May 1, 2016 \\
\hline \multicolumn{3}{|c|}{ Unnamed Project } \\
\hline Repicications: 1 & $\begin{array}{l}\text { Jurs } \\
\text { 'erformance Indicator }\end{array}$ & \\
\hline $\begin{array}{l}\text { System } \\
\text { Number Out }\end{array}$ & $\begin{array}{l}\text { Averaye } \\
95\end{array}$ & \\
\hline
\end{tabular}

Gambar 4.21 Entities Replikasi 1

Dapat dilihat number out pada replikasi 1 sebesar 95, dan nilai sama dengan yang ada pada model simulasi.

\begin{tabular}{|c|c|c|}
\hline 4:47:02PM & Category Overview & May 1,2016 \\
\hline \multicolumn{3}{|l|}{ Unnamed Project } \\
\hline \multicolumn{3}{|c|}{ Time Units: Hours } \\
\hline & Key Performance Indicators & \\
\hline $\begin{array}{l}\text { System } \\
\text { Number Out }\end{array}$ & $\begin{array}{c}\text { Averaye } \\
93\end{array}$ & \\
\hline
\end{tabular}

Gambar 4.22 Entities Replikasi 2

Dapat dilihat number out pada replikasi 2 sebesar 93, dan nilai sama dengan yang ada pada model simulasi.

\begin{tabular}{|c|c|c|}
\hline 4:48:33PM & Category Overview & May 1,2016 \\
\hline \multicolumn{3}{|l|}{ Unnamed Project } \\
\hline Replicalions: 3 & Time Units: $\quad$ Hours & \\
\hline \multicolumn{3}{|c|}{ Key Performance Indicators } \\
\hline $\begin{array}{l}\text { System } \\
\text { Number Out }\end{array}$ & $\begin{array}{l}\text { Average } \\
\text { 92 }\end{array}$ & \\
\hline
\end{tabular}

Gambar 4.23 Entities Replikasi 3

Dapat dilihat number out pada replikasi 3 sebesar 92, dan nilai sama dengan yang ada pada model simulasi.

\begin{tabular}{|c|c|c|}
\hline 4:49:42PM & Category Overview & May 1,2016 \\
\hline \multicolumn{3}{|l|}{ Unnamed Project } \\
\hline \multirow[t]{2}{*}{ Repilcations: 4} & Time Units: Hours & \\
\hline & Key Performance Indicators & \\
\hline $\begin{array}{l}\text { System } \\
\text { Number out }\end{array}$ & $\underset{\substack{\text { Average } \\
93}}{9}$ & \\
\hline
\end{tabular}

Gambar 4.24 Entities Replikasi 4

Dapat dilihat number out pada replikasi 4 sebesar 93, dan nilai sama dengan yang ada pada model simulasi.

\begin{tabular}{|c|c|c|}
\hline 4:50:46P M & Category Overview & May 1,2016 \\
\hline \multicolumn{3}{|l|}{ Unnamed Project } \\
\hline Replications: 5 & Time Units $\quad$ Hours & \\
\hline & Key Performance Indicators & \\
\hline $\begin{array}{l}\text { System } \\
\text { Number Out }\end{array}$ & $\begin{array}{l}\text { Average } \\
94\end{array}$ & \\
\hline
\end{tabular}

Gambar 4.25 Entities Replikasi 5
Dapat dilihat number out pada replikasi 5 sebesar 94, dan nilai sama dengan yang ada pada model simulasi.

\begin{tabular}{|c|c|c|}
\hline 4:53:59P M & Category Overview & May 1,2016 \\
\hline \multicolumn{3}{|l|}{ Unnamed Project } \\
\hline \multirow[t]{2}{*}{ Feplicaiions 6} & Time Unite: Hours & \\
\hline & Key Performance Indicators & \\
\hline $\begin{array}{l}\text { System } \\
\text { Number Out }\end{array}$ & $\begin{array}{l}\text { Average } \\
95\end{array}$ & \\
\hline
\end{tabular}

Gambar 4.26 Entities Replikasi 6

Dapat dilihat number out pada replikasi 6 sebesar 95, dan nilai sama dengan yang ada pada model simulasi.

\begin{tabular}{|c|c|c|}
\hline 4:54:53PM & Category Overview & May 1,2016 \\
\hline \multicolumn{3}{|c|}{ Unnamed Project } \\
\hline \multicolumn{3}{|c|}{ Time Unte $\quad$ Hours } \\
\hline & Key Performance Indicator & \\
\hline $\begin{array}{l}\text { System } \\
\text { Number Out }\end{array}$ & $\begin{array}{c}\text { Average } \\
94\end{array}$ & \\
\hline
\end{tabular}

Gambar 4.27 Entities Replikasi 7

Dapat dilihat number out pada replikasi 7 sebesar 94, dan nilai sama dengan yang ada pada model simulasi.

\begin{tabular}{|c|c|c|}
\hline 4:56:25PM & Category Overview & May 1,2016 \\
\hline \multicolumn{3}{|c|}{ Unnamed Project } \\
\hline \multirow[t]{2}{*}{ Feplications 8} & Timo Unitis: Hours & \\
\hline & Key Performance Indicator & \\
\hline $\begin{array}{c}\text { System } \\
\text { Number Out }\end{array}$ & $\begin{array}{l}\text { Average } \\
94\end{array}$ & \\
\hline
\end{tabular}

Gambar 4.28 Entities Replikasi 8

Dapat dilihat number out pada replikasi 8 sebesar 94, dan nilai sama dengan yang ada pada model simulasi.

\begin{tabular}{|c|c|c|}
\hline 4:57:22PM & Category Overview & May 1, 2016 \\
\hline \multicolumn{3}{|l|}{ Unnamed Project } \\
\hline \multicolumn{3}{|l|}{ Replications: 9} \\
\hline & Key Performance Indicators & \\
\hline $\begin{array}{l}\text { System } \\
\text { Number Out }\end{array}$ & $\begin{array}{c}\text { Average } \\
93\end{array}$ & \\
\hline
\end{tabular}

Gambar 4.29 Entities Replikasi 9

Dapat dilihat number out pada replikasi 9 sebesar 93, dan nilai sama dengan yang ada pada model simulasi. 


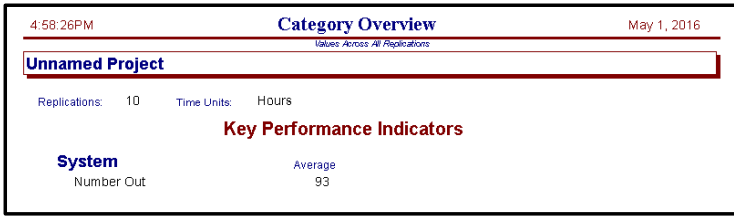

Gambar 4.30 Entities Replikasi 10

Dapat dilihat number out pada replikasi 10 sebesar 93, dan nilai sama dengan yang ada pada model simulasi.

Berikut adalah rekapitulasi pada penjumlahan replikasi antara lain sebagai berikut:

Tabel 4.4 Rekapitulasi pada Penjumlahan Replikasi

\begin{tabular}{|c|c|}
\hline Replikasi & Output Simulasi \\
\hline 1 & 95 \\
\hline 2 & 93 \\
\hline 3 & 92 \\
\hline 4 & 93 \\
\hline 5 & 94 \\
\hline 6 & 95 \\
\hline 7 & 94 \\
\hline 8 & 94 \\
\hline 9 & 93 \\
\hline 10 & 93 \\
\hline Rata-rata & 93,6 \\
\hline Standar Deviasi (SD) & 0,96 \\
\hline Variansi & 0,93 \\
\hline
\end{tabular}

Sumber: Pengolahan Data PT.TIKI (2016)

Rata-Rata:

$$
\begin{aligned}
\bar{X} & =\frac{(95+93+92+93+94+95+94+94+93+93}{10} \\
& =\frac{936}{10} \\
& =93,6
\end{aligned}
$$

Variansi:

$\mathrm{S}^{2}=\frac{\sum\left(\mathrm{X}_{\mathrm{i}}-\overline{\mathrm{X}}\right)^{2}}{\mathrm{n}-1}$

$$
\begin{aligned}
= & \begin{array}{l}
(95-93,6)+(93-93,6)+(92-93,6)+(93-93,6)+(94-93,6) \\
+(95-93,6)+(94-93,6)+(94-93,6)+(93-93,6)+(93-93,6)
\end{array} \\
10-1 & (1,4)+(-0,6)+(-1,6)+(-0,6)+(0,4) \\
= & \frac{+(1,4)+(0,4)+(0,4)+(-0,6)+(-0,6)}{10-1} \\
= & \frac{8,37}{9}
\end{aligned}
$$

$=0,93$

Std Deviasi:

$\mathrm{S}=\sqrt{\frac{\sum\left(X i-\bar{X}^{2}\right.}{n-1}}$

$=$

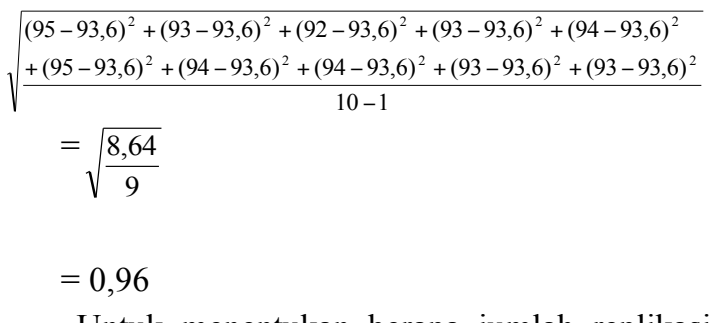

Untuk menentukan berapa jumlah replikasi yang dibutuhkan dilakukan perhitungan jumlah replikasi. Terdapat dua metode untuk menghitung jumlah replikasi yaitu metode absolute error dan metode relative error. Dalam kasus ini metode yang digunakan adalah metode absolute error. Sedangkan selang kepercayaan yang digunakan adalah $95 \%$.

Berikut ini adalah perhitungannya:

$$
\begin{aligned}
\mathrm{n} & =10 \\
\mathrm{n}-1 & =9 \\
\mathrm{hw} & =\frac{\left(t_{n-1}, \alpha / 2\right) x s}{\sqrt{n}} \\
& =\frac{2,262 \times 0,93}{\sqrt{10}} \\
& =0,69
\end{aligned}
$$

Jadi perhitungan replikasinya adalah sebagai berikut :

$$
\begin{aligned}
\mathrm{n}^{\prime} & =\left[\frac{\left(Z_{0,05 / 2} x s\right)}{\beta}\right]^{2} \\
& =\left[\frac{1,96 \times 0,93}{0,69}\right]^{2} \\
& =7,50 \approx 8
\end{aligned}
$$

Dari perhitungan yang telah dilakukan diperoleh jumlah minimal replikasi yang dibutuhkan yaitu sebanyak 8 replikasi.

2. Validasi Arena

Validasi adalah proses membandingkan model simulasi dengan real system. Terdapat dua metode yang dapat digunakan untuk membandingkan dua alternatif desain sistem, yaitu Welch Confidence Interval dan Paired - $t$ Confidence. Model dikatakan valid apabila antara output nyata dan output simulasi tidak berbeda secara signifikan. 
Tabel 4.5 Paired - $t$ Confidence

\begin{tabular}{|c|c|c|c|}
\hline $\begin{array}{c}\text { Replika } \\
\text { si }\end{array}$ & $\begin{array}{c}\text { Output } \\
\text { Simulasi }\end{array}$ & $\begin{array}{c}\text { Outpu } \\
\boldsymbol{t} \\
\text { Nyata }\end{array}$ & $\begin{array}{c}\text { Throughp } \\
\text { ut } \\
\text { Difference }\end{array}$ \\
\hline 1 & 124 & 120 & 4 \\
\hline 2 & 116 & 120 & -4 \\
\hline 3 & 113 & 120 & -7 \\
\hline 4 & 113 & 120 & -7 \\
\hline 5 & 114 & 120 & -6 \\
\hline 6 & 117 & 120 & -3 \\
\hline 7 & 116 & 120 & -4 \\
\hline 8 & 114 & 120 & -6 \\
\hline
\end{tabular}

Sumber: Pengolahan Data PT. TIKI (2016)

1. Perhitungan Validasi Output Simulasi setelah perhitungan replikasi

a. Rata-rata keseluruhan data

$$
\begin{aligned}
\mathrm{X} & =\frac{\sum \mathrm{X}_{\mathrm{i}}}{\mathrm{n}} \\
& =\frac{(124+116+113+113+114+117+116+114)}{8} \\
& =\frac{927}{8} \\
& =115,87
\end{aligned}
$$

b. Variansi

$$
\begin{aligned}
\mathrm{S}^{2} & =\frac{\sum\left(\mathrm{X}_{\mathrm{i}}-\overline{\mathrm{X}}\right)^{2}}{\mathrm{n}-1} \\
& =\frac{90,87}{7} \\
& =12,98
\end{aligned}
$$

c. Standar Deviasi

$$
\begin{aligned}
& \sigma=\sqrt{\frac{\sum\left(\mathrm{x}_{\mathrm{i}}-\bar{X}\right)^{2}}{\mathrm{n}-1}} \\
& = \\
& (124-115,87)^{2}+(116-115,87)^{2}+(113-115,87)^{2} \\
& +(113-115,87)^{2}+(114-115,87)^{2}+(117-115,87)^{2} \\
& 1 \frac{+(116+115,87)^{2}+(114-115,87)^{2}}{8-1} \\
& =\sqrt{\frac{12,6}{7}} \\
& =3,60
\end{aligned}
$$

2. Perhitungan Validasi Output nyata setelah perhitungan replikasi

a. Rata-rata keseluruhan data

$$
\begin{aligned}
X & =\frac{\sum \mathrm{X}_{\mathrm{i}}}{\mathrm{n}} \\
& =\frac{(120+120+120+120+120+120+120+120)}{8} \\
\mathrm{X} & =\frac{960}{8}
\end{aligned}
$$

$$
=120
$$

b. Variansi

$$
\mathrm{S}^{2}=\frac{\sum\left(\mathrm{X}_{\mathrm{i}}-\overline{\mathrm{X}}\right)^{2}}{\mathrm{n}-1}
$$

$$
(120-120)^{2}+(120-120)^{2}+(120-120)^{2}
$$$$
+(120-120)^{2}+(120-120)^{2}+(120-120)^{2}
$$$$
=\frac{+(120-120)^{2}+(120-120)^{2}}{10-1}
$$

$$
=0
$$

c. Standar Deviasi

$$
\sigma=\sqrt{\frac{\sum\left(\mathrm{x}_{\mathrm{i}}-\bar{X}\right)^{2}}{\mathrm{n}-1}}
$$

$$
=
$$

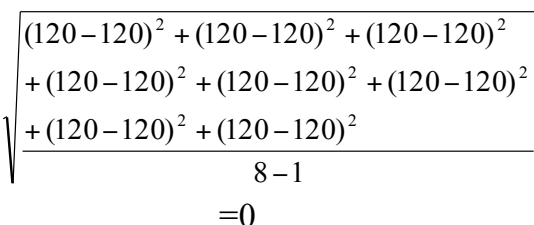

Hipotesa :

$$
\begin{array}{ll}
\text { Ho } & : \mu_{1}-\mu_{2}=0 \\
H_{1}: \mu_{1}-\mu_{2} & \neq 0
\end{array}
$$$$
\text { Ho }: \mu_{1}-\mu_{2}=\text { Tidak ada perbedaan yang }
$$
signifikan antara output sistem nyata dengan output sistem model.

$\mathrm{H}_{1} \quad: \mu_{1}-\mu_{2} \quad \neq$ Ada Perbedaan yang signifikan antara output sistem nyata dengan output sistem model.

Dengan level signifikan $\alpha=0,05$, maka didapatkan sebagai berikut :

$$
\begin{aligned}
h w & =\frac{\left(\mathrm{t}_{\mathrm{n}-1, \alpha / 2}\right) \times \mathrm{s}}{\sqrt{\mathrm{n}}} \\
& =\frac{(2,364 \times 5,69)}{\sqrt{8}} \\
& =\frac{13,45}{2,82}=4,76
\end{aligned}
$$

Sehingga confidence interval-nya adalah :

$$
=\left[\left(\overline{X_{1}}-\overline{X_{2}}\right)-h w \leq \mu 1-\mu 2 \leq\left(X_{1}-X_{2}\right) \overline{+}\right.
$$
$h w]$

$$
\begin{aligned}
& =-4,125-4,76 \leq \mu 1-\mu 2 \leq-4,125+4,76 \\
& =-8,88 \leq \mu 1-\mu 2 \leq 0,636
\end{aligned}
$$

Karena nilai 0 berada pada rentang $\mu 1$ $\mu 2$, maka keputusannya adalah Ho diterima, dengan demikian dapat diambil kesimpulan tidak ada perbedaan yang signifikan antara output sistem nyata dengan output model simulasi. Dengan kata lain model simulasi yang telah dibuat valid. 


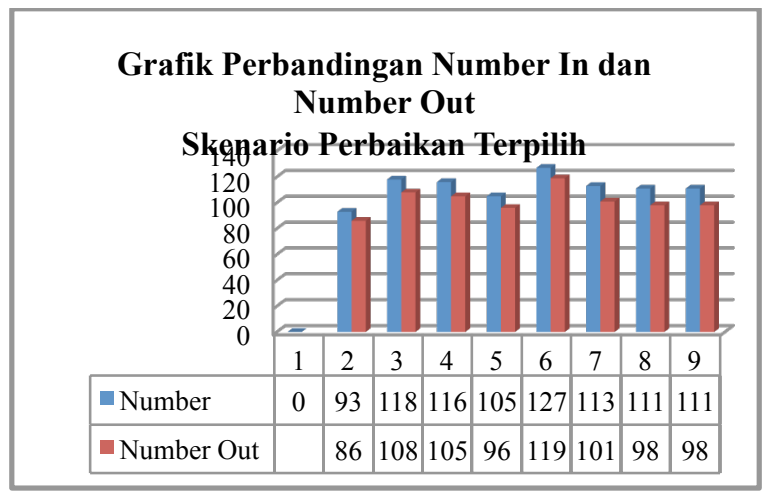

Dari hasil Process Analyzer NumberIn dan Number Out dapat dilihat jumlah rata rata dari masing-masing Server yang ada di PT.TIKI baik pada simulasi eksisting maupun di skenario usulan 1, 2 dan skenario usulan 3 dan data diatas number In dan Number Out yang terbaik yaitu Skenario 3, hal ini dirasakan optimal karena perusahaan tidak perlu menambah lebih banyak loket karena dengan hanya menambahkan 3 loket sudah tidak ada yang mengantri hal ini dapat dilihat dari output process analyzer pada waiting time dan utilitas. Maka dari itu dipilih skenario 3 sebagai skenario usulan.

\section{Kesimpulan}

Kesimpulan dalam pembuatan laporan kerja praktek dapat diuraikan sebagai berikut:

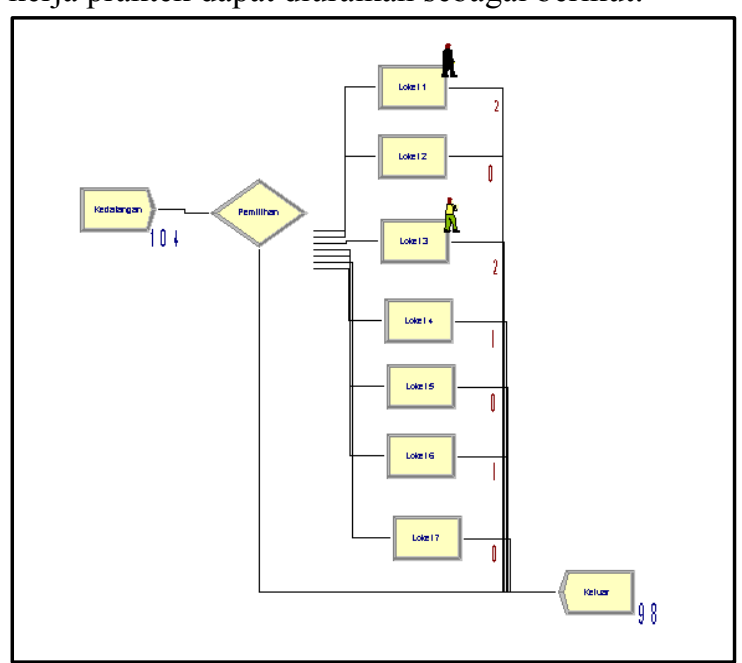

Gambar 5.1 Skenario 3 Menjadi Skenario Terpilih

Loket optimal didapatkan pada skenario 3 karena nilai waiting time yang didapatkan sebesar 0,119 dan utilitas sebesar 0,5686 yang dimana dapat dikatakan bahwa loket berada dalam kegiatan normal dan tidak sibuk.

\section{Saran}

Saran yang diberikan pada perusahaan dan peneliti selanjutnya adalah sebagai berikut:

1. Untuk perusahaan PT. TIKI jalan Teuku Umar sebaiknya menambah loket pembayaran, karena loket pembayaran yang terdapat di sekarang belum cukup untuk melayani customer yang datang.

2. Untuk peneliti selanjutnya diharapkan mampu memberikan sumbangan pengetahuan terhadap ilmu pemodelan sistem sehingga dapat diaplikasikan dalam kehidupan sehari-hari.

\section{Daftar Pustaka}

Adriana. H, Perbaikan Sistem Pelayanan Pendaftaran Pasien Loket Satu Jamkesmas Di RSUD Rd. Moewardi Surakarta Dengan Metode Business Process Improvement Dan Simulasi. Surakarta. 2010

Ahse. N. S, dkk, Analisis Sistem Antrian Untuk Menentukan Tingkat Pelayanan Yang Optimal Pada Kasir (Server) Rumah Makan Kober Mie Setan Malang Dengan Metode Simulasi. Malang.2012

Ginting P. J, Analisis Sistem Antrian Dan Optimalisasi L ayanan Teller (Studi Kasus Pada Bank X di Kota Semarang). Semarang. 2013

Gurusinga. P, Sibarani. R, Analisis Rata-rata Nilai Fisika Dengan Metode Ekspositori dan Inkuiri Di Fakultas Teknik Universitas Satya Negara Indonesia. Jakarta. 2011

Handoko. L. M, Penyusunan Standar Operasional Prosedur Pada Operasional Toko di Supermarket UFO (United Fashion Outlet). Surabaya. 2013

Hardiwinoto, Perilaku Rasional Para Manajer Dalam Pengambilan Keputusan Pembiayaan Melalui Bank Syariah. Semarang. 2011

Julasmari. F dan Rahmadani. D, Simulasi Antrian Pelayanan Kasir Swalayan Citra di Bandar Buat, Padang. Padang. 2011

Law. A. M. dan Kelton. W. D, Simulation Modelling And Analysis, Second Edition, 
Mc-Graw-Hill: International. Singapura. 1991

Nursanti. I, dkk, Analisis Perbaikan Sistem Antrian Pelanggan Skin Care XYZ Dengan Menggunakan Model Simulasi. Surakarta. 2015

Sayuti. A. J, Pentingnya Standar Operasional Prosedur Kerja Untuk Meningkatkan Kinerja Karyawan Dalam Perusahaan. Palembang. 2012

Setia Budi. H. P dan Siswanto. N, Simulasi Perbaikan Proses Bisnis Instalasi Gawat Darurat Dengan Metode Event-Driven Process Chain (EPC) (Studi Kasus: RSU Haji Surabaya). Surabaya. 2012

Staublish, M. J, Pujawan, I. N, Evaluasi Dan Simulasi Perbaikan Order Fulliment Process Pada Pupuk Urea Bersubsidi Dengan Pendekatan Lean Distribution (Studi Kasus: Kantor Pemasaran Jatim PT. Pupuk Kaltim Tbk). Surabaya. 2009

Sugiarto. F dan Buliali. J. L,Implementasi Simulasi Sistem Untuk Optimasi Proses Produksi Pada Perusahaan Pengalengan Ikan. Surabaya.2002

Wahyuningsih. S, Perancangan Aplikasi Sistem Antrian Service Mobil Pada Bengkel Waris Sibolga Menggunakan Metode Multi Channel - Multi Server. Medan. 2013 